\title{
Effect of Growing Media and Fertigation Schedules on Growth and Yield of Cucumber (Cucumis sativus L.) under Polyhouse Condition
}

\author{
Kumari Lata $^{1 *}$, M.R. Choudhary ${ }^{1}$, Raunak Sharma ${ }^{1}$ and Ashish S. Ghormade ${ }^{2}$ \\ ${ }^{1}$ Department of Horticulture, S.K.N. College of Agriculture, Jobner-Jaipur, India \\ ${ }^{2}$ Department of Floriculture, Dr. YSP UHF, Nauni-Solan, India \\ *Corresponding author
}

\section{A B S T R A C T}

\section{Keywords}

Growing media,

Fertigation

schedules,

Cucumber, Growth,

Yield, Polyhouse

Article Info

Accepted:

12 November 2018

Available Online:

10 December 2018
An experiment was conducted to study the "Effect of growing media and fertigation schedules on growth and yield of cucumber (Cucumis sativus L.) under polyhouse condition" during kharif season of 2016 at Department of Horticulture, S.K.N. College of Agriculture, Jobner. The growing media: garden soil $18 \mathrm{~kg} / \mathrm{bag}+$ vermicompost $2 \mathrm{~kg} / \mathrm{bag}$ + cocopeat $2 \mathrm{~cm}$ layer at top shows the increase in all growth characters (chlorophyll and number of days taken to first flower appearance), yield attributes [number of fruits per vine, average fruit weight and fruit yield per $\left.1000 \mathrm{~m}^{2}(11.89 \mathrm{t})\right]$, quality attributes (TSS, ascorbic acid, N, P, K content in fruits). The treatment fertigation schedule at 2 days interval provide higher value for all growth characters (chlorophyll and number of days taken to first flower appearance), yield attributes [of fruits per vine, average fruit weight and fruit yield per $1000 \mathrm{~m}^{2}$ (9.75 t)], quality attributes (TSS, ascorbic acid, N, P, K content in fruits).

\section{Introduction}

The cucumber (Cucumis sativus L.) is essentially a warm season crop mainly grown in tropical and subtropical regions where it is cultivated in the field. This crop belonging to family cucurbitaceace is generally known as "cucurbits". It consist of a wide range of vegetables either used for salad purpose (cucumber) or for cooking (all gourds), pickling (West Indian Gherkin) or as desert fruit (musk melon, water melon) or candiel or preserved (ash gourd). As a group, cucurbits occupy the largest area in India and in other tropical countries. Cucumber (Cucumis sativus L.) is commonly known as khira, dosakagu, sukasa, kakri, vellarikki and kakrikai. Cucumber is one of the oldest cultivated vegetable crops having its origin probably in India. It has been known in history for over 3000 years. From India, it seems to have spread to Asia and Africa and then to Europe. It was ancient Greeks and Romans in about 300 B.C. (Tekale et al., 2014).

A growing medium is a substance through which roots grow and extract water and nutrients. Media for vegetable crops are 
composed of soil and different organic matters. The soil is generally used as a basic medium because it is cheapest and easy to procure. Soil can be supplemented with the organic matters by adding vermicompost, farm yard manure, cocopeat etc. to enrich adequate nutrients for the plants. The growing medium also plays an important role in seed germination not only it act as a support, but also a source of key nutrients for plant growth. The composition of the medium influence the quality of the seedling (Wilson et al., 2001). There is a better relationship between the manure and rooting rather than conventional soil mix and less susceptibility of the seedlings to soil borne pest and disease (Akanbi et al., 2002).

The fertigation saves about 25 to 30 per cent of fertilizers coupled with higher productivity and quality (Raman et al., 2000). As the fertilizer is the costly input it is very essential to increase the fertilizer use efficiency by standardizing the fertigation schedule for various crops. Cucumber is one of the most important crop grown in protected condition for achieving higher productivity. However, there is no specific recommendation about scheduling of fertigation. Very meager research work has been carried out on apportioning or scheduling of fertilizers, hence there is scope to increase the productivity of cucumber by adopting suitable fertigation level and schedule. Hence the present research work has carried out to study the effect of fertigation levels and schedules on the growth, yield and quality of cucumber grown under polyhouse condition.

\section{Materials and Methods}

A field experiment was conducted during 'Kharif' season of the year 2016 at Horticulture farm S.K.N. College of Agriculture, Jobner, Jaipur at $75^{\circ} 28^{\prime}$ longitude and $26^{\circ} 05^{\prime}$ latitude and altitude of
427 metres above mean sea level. The experiment was laid out in randomized block design with three replications under polyhouse condition. the experiment comprised 18 treatment combinations. 6 combination of growing media [Garden soil (GS) $20 \mathrm{~kg}$ per bag $\left(\mathrm{G}_{0}\right)$, Garden soil (GS) $20 \mathrm{~kg}$ per bag + Cocopeat $2 \mathrm{~cm}$ layer at top $\left(\mathrm{G}_{1}\right)$, GS $15 \mathrm{~kg}$ per beg + FYM $5 \mathrm{~kg}$ per beg $\left(\mathrm{G}_{2}\right)$, GS $18 \mathrm{~kg}$ per bag + Vermicompost $2 \mathrm{~kg}$ per bag $\left(\mathrm{G}_{3}\right)$, GS 15 kg per beg + FYM $5 \mathrm{~kg}$ per beg + Cocopeat 2 cm layer at top $\left(\mathrm{G}_{4}\right)$, GS $18 \mathrm{~kg}$ per bag + Vermicompost $2 \mathrm{~kg}$ per bag + Cocopeat $2 \mathrm{~cm}$ layer at top $\left.\left(\mathrm{G}_{5}\right)\right]$ and 3 fertigation schedules [equal amount of fertilizers (19:19:19, 0:0:50, urea, $\mathrm{CaNO}_{3}, \mathrm{MgSO}_{4}$ and borex)] were applied at 2 days $\left(S_{1}\right), 4$ days $\left(S_{2}\right)$ and 6 days $\left(S_{3}\right)$ interval. Garden soil was collected from Horticulture farm by removing surface soil upto a depth of $5 \mathrm{~cm}$. The texture of soil was loamy sand (entisol) with $\mathrm{pH} 8.2$, ECe 1.35 $\mathrm{dSm}^{-1}$, organic carbon $0.20 \%$, available nitrogen $135 \mathrm{~kg} \mathrm{ha}^{-1}$, available phosphorus $16.25 \mathrm{~kg}$.

Leaf sample of cucumber was collected from the field as per standard procedure at flowering for chlorophyll content and fruit sample collected at second and third harvesting for TSS, ascorbic acid, N, P, K content of fruits. TSS was estimated in ${ }^{0}$ Brix with the help of hand refractometer and ascorbic acid (Vitamin C) content was estimated by the dichlorophenol indophenols dye method, and expressed in mg/100 g. Fruit sample were dried and ground for analysis of $\mathrm{N}, \mathrm{P}, \mathrm{K}$ content of fruits. Nitrogen was estimated by Colorimetric method as suggested by Snell and Snell (1939) using the Spectronic-20 (Model SL-177). Phosphorus was estimated by digesting fruit sample with tri-acid mixture of $\mathrm{HNO}_{3}: \mathrm{H}_{2} \mathrm{SO}_{4}: \mathrm{HClO}_{4}$ (10:1:4) using Vanadomolybdo Phosphate yellow colour method and the intensity of colour was measured at $470 \mathrm{~nm}$ in a spectrophotometer (Jackson, 1973). Potassium 
was estimated by digesting leaf sample with tri-acid mixture of $\mathrm{HNO}_{3}: \mathrm{H}_{2} \mathrm{SO}_{4}: \mathrm{HClO}_{4}$ (10:1:4) and was estimated by flame photometer as per the method as suggested by Bhargava and Raghupathi (1993). Data generated from the experimental plots were analysed using SAS 9.3 version of the statistical package (SAS Institute Inc, 2011). Analysis of variance (ANOVA) was performed using PROCANOVA. Means were separated using Fisher's least significant difference (LSD) test at a probability level of $\mathrm{pd}$ d" 0.05 .

\section{Results and Discussion}

The data regarding the effect of growing media and fertigation schedules have been summarized and presented as mean of single year (2016).

\section{Effect of growing media}

Significantly higher values for chlorophyll content in leaves and optimum days taken for first flower appearance were recorded under treatment $\mathrm{G}_{5}$ (soil + vermicompost + cocopeat) over other treatments although, treatment $\mathrm{G}_{4}$ (soil + FYM + cocopeat) remained statistically at par to it for chlorophyll content (Table 1).

Treatment $\mathrm{G}_{5}$ (soil + vermicompost + cocopeat) registered significantly higher values for number of fruits per vine, average fruit weight and fruit yield per $1000 \mathrm{~m}^{2}$ over rest of treatments and remained at par to $G_{4}$ (soil + FYM + cocopeat) for number of fruits per vine (Table 1). Higher values for yield attributes might be due to higher accessibility of chemical fertilizers through fertigation and vermicompost which can induce protein production that causes more meristem cells and cell division and finally led to higher average fruit weight of cucumber and finally yield (Salardini and Mojtahedi, 1988).
Significantly higher values for TSS, ascorbic acid content, nitrogen, phosphorus and potassium content were recorded in treatment $\mathrm{G}_{5}$ (soil + vermicompost + cocopeat) and minimum with $\mathrm{G}_{0}$ (soil). Treatment $\mathrm{G}_{5}$ was found significantly superior over rest of the treatments although, treatment $\mathrm{G}_{5}$ and $\mathrm{G}_{4}$ were found statistically at par with each other for TSS, phosphorus and potassium content (Table 1). Increase in ascorbic acid and TSS content of fruit in could be attributed to better growing media which helped in better uptake of NPK nutrients including micronutrients which inurn influence the quality traits in cucumber. The results are in conformity with the findings of Grimstand (1990), Koodzeij and Kostecka (1994) and Asano (1994) in cucumber.

\section{Effect of fertigation schedules}

Perusal of data in table 1 reveals that treatment $\mathrm{S}_{1}$ (fertigation at 2 days interval) was recorded significantly maximum values for chlorophyll content at 45 days and optimum days taken for first flower appearance over rest of the treatments. This might be due to frequent and increased application of fertilizers directly in the vicinity of the root zone increases the availability and uptake of nutrients which leads to increase the cell size and cell elongation resulted in healthy and vigorous plant growth.

These results were in accordance with Lee et al., (2005), Eifediyi and Remison (2009), Sharma et al., (2009) and Jilani et al., (2009). Also, the frequent application at 2 days interval increases the availability of nutrients leads to increases the uptake of $\mathrm{N}, \mathrm{P}$ and $\mathrm{K}$ during growth period which increased protein and protoplasm synthesis for higher rate of mitosis resulted in increase the growth attributes. These results are in agreement with those reported by Al-Jaloud et al., (1999) and Shinde et al., (2010). 
Table.1 Effect of growing media and fertigation schedules on growth, yield and quality parameters of cucumber

\begin{tabular}{|c|c|c|c|c|c|c|c|c|c|c|}
\hline Treatments & $\begin{array}{c}\text { Chlorop } \\
\text { hyll } \\
(\mathrm{mg} / \mathrm{g})\end{array}$ & $\begin{array}{l}\text { First flower } \\
\text { appearance( } \\
\text { days) }\end{array}$ & $\begin{array}{l}\text { No. of } \\
\text { fruits } \\
\text { per } \\
\text { vine }\end{array}$ & $\begin{array}{l}\text { Average } \\
\text { fruit } \\
\text { weight } \\
(\mathrm{g})\end{array}$ & $\begin{array}{c}\text { Fruit } \\
\text { yield per } \\
1000 \mathrm{~m}^{2} \\
(\mathrm{t})\end{array}$ & $\begin{array}{c}\text { Ascorbic } \\
\text { acid } \\
(\mathrm{mg} / 100 \mathrm{~g})\end{array}$ & $\begin{array}{l}\text { TSS } \\
\left({ }^{\circ} \text { Brix }\right)\end{array}$ & $\begin{array}{l}\text { Nitrogen } \\
(\mathrm{mg} / 100 \mathrm{~g})\end{array}$ & $\begin{array}{l}\text { Phosphor- } \\
\text { us } \\
(\mathrm{mg} / 100 \mathrm{~g})\end{array}$ & $\begin{array}{c}\text { Potassiu- } \\
\mathrm{m} \\
(\mathrm{mg} / 100 \mathrm{~g})\end{array}$ \\
\hline \multicolumn{11}{|l|}{ Growing Media: } \\
\hline $\mathrm{G}_{0}: \mathbf{G S}(20 \mathrm{~kg})$ & 0.874 & 25.19 & 22.29 & 147.96 & 5.31 & 6.51 & 3.02 & 95.20 & 21.89 & 138.38 \\
\hline $\mathrm{G}_{1}: \mathbf{G S}(20 \mathrm{~kg})+\mathbf{C C}$ & 0.883 & 27.52 & 22.58 & 153.15 & 5.57 & 6.65 & 3.04 & 96.22 & 22.07 & 138.71 \\
\hline $\mathrm{G}_{2}:$ GS $(15 \mathrm{~kg})+$ FYM $(5 \mathrm{~kg} / \mathrm{bag})$ & 0.885 & 28.67 & 37.52 & 161.12 & 9.72 & 6.68 & 3.05 & 97.47 & 22.30 & 139.80 \\
\hline $\mathrm{G}_{3}: \mathrm{GS}(18 \mathrm{~kg})+\mathrm{VC}(2 \mathrm{~kg} / \mathrm{bag})$ & 0.891 & 30.14 & 37.77 & 167.4 & 10.17 & 6.69 & 3.07 & 98.43 & 22.57 & 140.19 \\
\hline $\begin{array}{l}\mathrm{G}_{4}: \text { GS }(15 \mathrm{~kg})+\text { FYM }(5 \mathrm{~kg} / \mathrm{bag})+ \\
\text { CC }\end{array}$ & 0.896 & 31.38 & 38.33 & 181.69 & 11.21 & 6.84 & 3.09 & 100.38 & 22.78 & 140.57 \\
\hline $\begin{array}{l}\mathrm{G}_{5}: \mathrm{GS}(18 \mathrm{~kg})+\mathrm{VC}(2 \mathrm{~kg} / \mathrm{bag})+ \\
\mathrm{CC}\end{array}$ & 0.900 & 32.64 & 38.96 & 189.51 & 11.89 & 7.12 & 3.12 & 102.26 & 23.01 & 141.18 \\
\hline $\mathrm{SEm} \pm$ & 0.001 & 0.19 & 0.41 & 1.19 & $\mathbf{0 . 1 0}$ & 0.08 & 0.02 & 0.63 & 0.09 & 0.27 \\
\hline $\mathrm{CD}(\mathrm{P}=0.05)$ & 0.004 & 0.52 & 1.14 & 3.34 & 0.27 & 0.23 & 0.05 & 1.77 & 0.25 & 0.77 \\
\hline \multicolumn{11}{|l|}{ Fertigation Schedules: } \\
\hline$S_{1}$ : at 2 days interval & 0.896 & 32.03 & 34.78 & 172.10 & 9.75 & 6.96 & 3.09 & 100.82 & 22.82 & 140.49 \\
\hline$S_{2}$ : at 4 days interval & 0.888 & 30.05 & 33.45 & 170.04 & 9.27 & 6.83 & 3.06 & 97.88 & 22.65 & 140.07 \\
\hline$S_{3}$ : at 6 days interval & 0.881 & 25.69 & 30.5 & 158.28 & 7.91 & 6.45 & 3.04 & 96.29 & 21.85 & 138.86 \\
\hline SEm \pm & 0.001 & 0.13 & 0.29 & 0.84 & 0.07 & 0.06 & 0.01 & 0.45 & 0.06 & 0.19 \\
\hline $\mathrm{CD}(\mathrm{P}=0.05)$ & 0.003 & 0.37 & 0.80 & 2.36 & 0.19 & 0.16 & $\mathbf{0 . 0 3}$ & 1.25 & 0.18 & 0.54 \\
\hline Interaction & Sig & Sig & Sig & Sig & Sig & NS & NS & Sig & Sig & NS \\
\hline
\end{tabular}

GS: Garden soil; FYM: Farm Yard Manure; VC: Vermicompost; CC: Cocopeat $2 \mathrm{~cm}$ layer at top

*Optimum no. of days for flower appearance in terminator variety of cucumber is 32-35DAS 
Significantly maximum number of fruits per vine, average fruit weight and fruit yield per $1000 \mathrm{~m}^{2}$ were observed in treatment $\mathrm{S}_{1}$ (fertigation at 2 days interval) over $S_{2}$ (at 4 days) and $\mathrm{S}_{3}$ (at 6 days) (Table 1). The enhanced supply of nutrients through increased fertigation level in the root vicinity of plant maintain optimum nutrient concentration in the root zone throughout the crop growth period, which increases the uptake of moisture and nutrients resulted in increasing all the growth attributes of cucumber which increases the photosynthetic rate and absorbed APAR resulted in more translocation of photosynthates towards reproductive organ (sink) which ultimately increases the yield attributes of cucumber. Janapriya et al., (2010) also reported significantly higher yield and yield attributes under increased fertigation level. Similar results are also reported by Sharma et al., (2009), Dai et al., (2011) and Zhang et al., (2011). The supply of nutrients through fertigation in the required duration has helped in efficient uptake resulting in increased length and girth of the fruits. The results are in conformity with the results of Das et al., (1987), Choudhari and More (2002), Manohar (2002), Peil and Lopez (2002), Rodriguez et al., (2007), Sharma et al., (2009), Shinde et al., (2010).

Treatment $S_{1}$ (fertigation at 2 days interval) was recorded significantly maximum values for ascorbic acid, TSS, nitrogen, phosphorus and potassium content over rest of fertigation treatments, although it was remained at par to treatment $S_{2}$ (fertigation at 4 days interval) for values of ascorbic acid, TSS, phosphorus and potassium content. Fertigation is supplying fertilizers along with irrigation is one of the most effective convenient methods of supplying nutrients of water according to the specific requirements of the crop to maintain optimum soil fertility and to increase the quality of the produce (Shingure et al., 1999) might be the probable reason which led improvement in quality attributes of cucumber during experiment.

\section{References}

Akanbi, W.B., Togun, A.O., Adediran, T.A., Olabde, O. S. and Olanivi, J. O. 2002. Effect of split application of organomineral fertilizer on okra growth, nutrient uptake and fruit yield. Crop Research, 29 (2): 223-239

Al-Jaloud, A., Ongkingno, T., Al-Saharay, S. and Al-Bashir, W. 1999. Effect of fertigation frequencies on growth and yield of greenhouse cucumber. Saudi Journal of Biological Sciences, 2 (6): 156-166.

Asano, J. C. (1994). Effect of organic manures on quality of vegetables. Journal of Agricultural Research 18 (1): 31-36.

Bhargava, B.S. and Raghupathi, H.B. 1993. In: Method of analysis of Soil, Plant, Water and fertilizers. H. L. S. Tandon (Ed) F.D.C.O., New Delhi. pp 41.

Choudhari, S.M. and More, T. A. 2002. Fertigation, fertilizer and spacing requirement of tropical gynoecious cucumber hybrids. Acta Horticulturae, 588: 233-240.

Dai, J., Liu, S., Zhang, W., Xu, R., Luo, W., Zhang, S., Yin, X., Han, L. and Chen, W. 2011. Quantifying the effects of nitrogen on fruit growth and yield of cucumber crop in greenhouse. Scientia Horticulturae, 130: 551-561.

Das, M.K., Maity, T.K. and Som, M.G. 1987. Growth and yield of pointed gourd as influenced by nitrogen and phosphorus fertilization. Vegetable Science, 14 (1):18-26.

Eifediyi, E.K. and Remison, S.U. 2009. The effects of inorganic fertilizers on the yield of two varieties of cucumber. Report and Opinion, 1 (5): 74-80 
Grimstand, S.O., 1990. Evaluation trials of greenhouse cucumbers. Verdiproving av veksthusagurk. Gartneryrket, 80 (21): 16-18.

Jackson, M.L. 1973. Soil chemical analysis. Prentice Hall of India Private Limited, New Delhi, India, pp. 183-192.

Janapriya, S., Palanisamyand, D. and Ranghaswami, M.V. 2010. Soilless media and fertigation for naturally ventilated polyhouse production of cucumber (Cucumis sativus L.) cv. green long. International Journal of Agricultural and Environment Biotechnology, 3 (2): 199-203.

Jilani, M.S., Bakar, A., Waseem, K. and Kiran, M. 2009. Effect of different levels of NPK on the growth and yield of cucumber (Cucumis sativus L.) under the plastic tunnel. Journal of Agriculture Social Sciences, 5: 99-101.

Koodzeij M and Kostecka J (1994). Some quality characteristics. In cucumber and carrot grown on vermicomposts. ZezytyNaukeme-Akademii-Roluicoz-ej-im-

Hugona-Koataja-w-karkowie, SerjaNaakowa, 41: 89-93.

Lee, J.H., Park, S.K., Lee, Y.H., Lee, Y.B. 2005. Effect of fertigation level and frequency on uptake of nutrients, growth and yield in cucumber. Journal of Korean Society for Horticultural Science, 46 (6): 356-362.

Manohar, K.R. 2002. Evaluation of capsicum (Capsicum annuum) genotypes and effect of source of fertilizers and levels of fertigation under cost effective green house. Ph. D (Agri.). Horticulture, Thesis submitted to UAS Bangalore.

Peil, R.M. and Lopez, J.G. 2002. Fruit growth and biomass allocation to the fruits in cucumber: effect of plant density and arrangement. Acta Horticulturae, 588: 75-80.

Raman, S.S., Murthy, K.M.D., Ramesh, G., Palaniappan, S.P. and Chelliah, S. 2000.
Effect of fertigation on growth and yield of gherkin. Veg. Sci. 27 (1): 64-66.

Rodriguez, J.C., Shaw, N.L. and Cantliffe, D.J. 2007. Influence of plant density on yield and fruit quality of greenhousegrown galia muskmelons. Hortculture Technology, 17 (4): 580-585.

Salardini, A., Mojtahedi, A. 1988. Principal of plant nutrition. University of Tehran Press, Tehran, Iran.

SAS Institute Inc. 2011. SAS 9.3 Macro Language: Reference. Cary, NC: SAS Institute Inc. SAS Institute. 1999. Statistical Analysis System Inc. J SAS users' guide, Statistical Analysis Institute. Carry NC, pp: 112

Sharma, M.K., Negi, S. and Kumari. S. 2009. Effect of different growing media and fertigation levels on production of cucumber (Cucumis sativus) under protected conditions in the hills. Indian Journal of. Agriculture Science, 79 (11): 853-856.

Shindhe, J.B., Malunjkar, B.D., Raut, R.S., Patil, P.D. and Thawal, D.W. 2010. Response of cucumber to fertigation under drip irrigation system. Bioinfoet, 7 (2): 161-164.

Shingure P S, Lallan Ram, Marathe R A and Yadav R P 1999. Effect of nitrogen fertigation on vegetative growth and leaf nutrient content of acid lime (Citrus aurantifolia Swingle) in central India. Indian Journal of Soil Conservation, 27 (1): 45-49.

Snell, F.D. and Snell, C.T. 1939. Colorimetric methods of analysis $3^{\text {rd }}$ Ed. 11 van Nortrand Co. Inc., New York.

Tekale, C.D., Tumbare, A.D., Tekale, G.S., Danawale, N.J. and Tambe, S.T. 2014. Effect of different fertigation levels and schedules on growth and yield of cucumber under polyhouse conditions. International Journal of Current Research, 6 (7): 7353-7355.

Wilson, S.B., Stoffella, P.J. and Graetz, D.A. 
2001. Use of compost as a media amendment for containerized production of two subtropical perennials. Journal of Environmental Horticulture, 19 (1): 37-42. response of cucumber to nitrogen fertilization under subsurface drip irrigation in solar greenhouse. Agricultural Sciences in China, 10 (6): 921-930.

Zhang, H., Chi, D., Wang, q., Fang, J. and Fang, X. 2011. Yield and quality

\section{How to cite this article:}

Kumari Lata, M.R. Choudhary1, Raunak Sharma1 and Ashish S. Ghormade. 2018. Effect of Growing Media and Fertigation Schedules on Growth and Yield of Cucumber (Cucumis sativus L.) under Polyhouse Condition. Int.J.Curr.Microbiol.App.Sci. 7(12): 1457-1463. doi: https://doi.org/10.20546/ijcmas.2018.712.173 